\title{
АРХЕОЛОГИЯ
}

DOI: http://dx.doi.org/10.15688/jvolsu4.2016.2.1

UDC 902“634”(477,7)

Submitted: 04.03.2016

LBC T4(43УKP7,5)24

Accepted: 29.03 .2016

\section{NEOLITHIC LAYER OF THE KALMIUS SETTLEMENT IN MARIUPOL. STONE CRAFTS}

\author{
Aleksandr V. Kolesnik \\ Candidate of Sciences (History), Associate Professor, \\ Department of Historiography, Source Study, Archaeology and Methods of Teaching History, \\ Donetsk State University \\ akolesnik2007@mail.ru \\ Universitetskaya St., 18, 83048 Donetsk, Ukraine
}

\section{Vladimir N. Gorbov}

Researcher,

Donetsk Republican (Regional) Museum

gorbov.vn@gmail.com

Chelyuskintsev St., 189-a, 83048 Donetsk, Ukraine

\begin{abstract}
The multilayer archaeological site Kalmius is situated on the right bank of the Kalmius river in historical center of Mariupol. The excavated area (2,8 $\mathrm{m}$ in depth) contains cultural layers of the 20th-19th, 18th centuries, Early Middle Age, Late Bronze Age and Neolithic Age. The site was excavated in 2010-2012, 2014. The Neolithic layer includes numerous flint, stone, pottery artifacts, fragments of animal bones. The collection of stone crafts from 2014 excavation is under discussion in the article. It includes about 1200 flint crafts, unique pieces of slabe and sandstone. The flint industry was based on knapping of prismatic cores. The flint blades of middle size $(100-120 \mathrm{~mm})$ are a framework of the industry. At the finish stage of exploitation the prismatic cores were modified as cuboid-sharped cores. Geometric microliths of various types, side-scrapers, "non-geometric microliths" and blade implements form the structures of tools assemblages. Burins and end-scrapers are absent. Abundant sources of a flint raw material are situated at the distance of about $120 \mathrm{~km}$ in the Southern Donbass (Krynka river basin). Flint raw materials are knapped completely. Non-utilized flint flakes more than $40 \mathrm{~mm}$ in size are rare. Intensive usage was provoked by a microlitism of a stone inventory. There are an "iron" and two sandstone plates among pieces of "soft" stone. Analogous complexes are famous in the basin of Lower Don region. The flint collection is similar to the flint complexes of the Mariupol burial place too.

Key words: Donbass, Neolithic age, flint complex, raw material strategies, microliths.

УДК 902“634”(477,7)

ББК Т4(43УКР7,5)24

Дата поступления статьи: 04.03.2016

Дата принятия статьи: 29.03.2016
\end{abstract}

\section{НЕОЛИТИЧЕСКИЙ СЛОЙ ПОСЕЛЕНИЯ КАЛЬМИУС В МАРИУПОЛЕ. КАМЕННЫЕ ИЗДЕЛИЯ}

\section{Александр Викторович Колесник}

Кандидат исторических наук, доцент, кафедра историографии, источниковедения, археологии и методики преподавания истории, 
Донецкий национальный университет

akolesnik2007@mail.ru

ул. Университетская, 18, 83048 г. Донецк, Украина

\section{Владимир Николаевич Горбов}

Научный сотрудник,

Донецкий республиканский краеведческий музей

gorbov.vn@gmail.com

ул. Челюскинцев, 189-а, 83048 г. Донецк, Украина

Аннотация. Многослойный археологический памятник Кальмиус расположен на правом берегу одноименной реки в историческом центре г. Мариуполь. В раскопе глубиной 2,9 м содержатся культурные слои XX-XIX, XVIII вв., раннего средневековья, позднего бронзового века и неолита. Памятник раскапывался в 2010-2012, 2014 годах. Слой неолитического времени содержал многочисленные кремневые изделия, фрагменты костей животных, фрагменты керамики, изделия из мягких пород камня. В настоящей статье подробно анализируются коллекция каменных изделий из материалов раскопа 2014 года. Коллекция включает около 1200 кремневых изделий, уникальные предметы из сланца и песчаника. Кремневая индустрия базировалась на расщеплении призматических нуклеусов. Основу индустрии составляли пластины средней величины, размерами до 100-120 мм. На последней стадии расщепления призматические нуклеусы приобретали кубовидные очертания. Основу орудий составляют геометрические микролиты разных типов, изделия из пластин, скребки на отщепах, «негеометрические микролиты». Спецификой кремневой индустрии является отсутствие резцов и концевых скребков. Обильные источники кремневого сырья находятся на расстоянии около 120 км в Южном Донбассе (бассейн р. Крынка). Каменное сырье расщеплялось до предела. Неиспользованные кремневые отщепы размерами более 40 мм единичны. Интенсивное использование сырья привело к микролитизации инвентаря. Среди орудий из «мягких» пород камня выделяются «утюжок» и две тонкие шлифованные плитки из песчаника. Аналогичные комплексы известны на Нижнем Дону. Коллекция кремневых изделий Мариупольского могильника содержит те же типы орудий, что и стоянка на правом берегу реки.

Ключевые слова: Донбасс, неолит, кремневый комплекс, сырьевые стратегии, микролиты.

\section{Введение}

Неолит степной зоны Северного Приазовья - важная составная часть неолита Восточной Европы. Изучение степного неолита насыщено яркими эпизодами, давно ставшими маркерами истории археологической науки. В их число входит широко известный Мариупольский неолитический могильник, исследованный Н.Е. Макаренко в 1930 г. на левом берегу р. Кальмиус [9] и породивший широкую дискуссию в археологии каменного века [6; 12; и др.]. Вопрос о поселенческом эквиваленте Мариупольского могильника и неолитических поселениях Донецкого Приазовья, в целом, никогда не сходил с повестки дня. Понятен поэтому интерес к новому неолитическому памятнику на правом берегу р. Кальмиус, в пределах городской застройки г. Мариуполя.

Местонахождение Кальмиус - многослойный археологический памятник в черте современного Мариуполя (рис. 1). Со- гласно исторической традиции, в этом месте располагалась крепость XVIII в. Кальмиус, предтеча современного г. Мариуполя. Памятник находится на мысу высокого (до 25 м) правого берега реки. Общая мощность слоя культурных напластований достигала 2,8 м. В ходе раскопок были изучены слои XX-XIX и XVIII вв., салтово-маяцкой культуры, позднего бронзового века и эпохи неолита. Стационарные раскопки памятника производились в 2011-2012 и 2014 годах. Исследования проводились Приазовской археологической экспедицией под руководством В.Н. Горбова [4].

Нижний слой памятника относится к неолитическому поселению. Слой этого времени обнаружен в раскопах 2012 и 2014 годов. В 2012 г. был раскопан участок площадью 42 кв. м, в 2014 г. - участок площадью 24 кв. м. Неолитические культурные остатки залегают в слое гумусированной супеси. В раскопе 2014 г. на юго-восточной окраине памятника слой залегал на глубине 1,9-2,3 м. 


\section{АРХЕОЛОГИЯ}
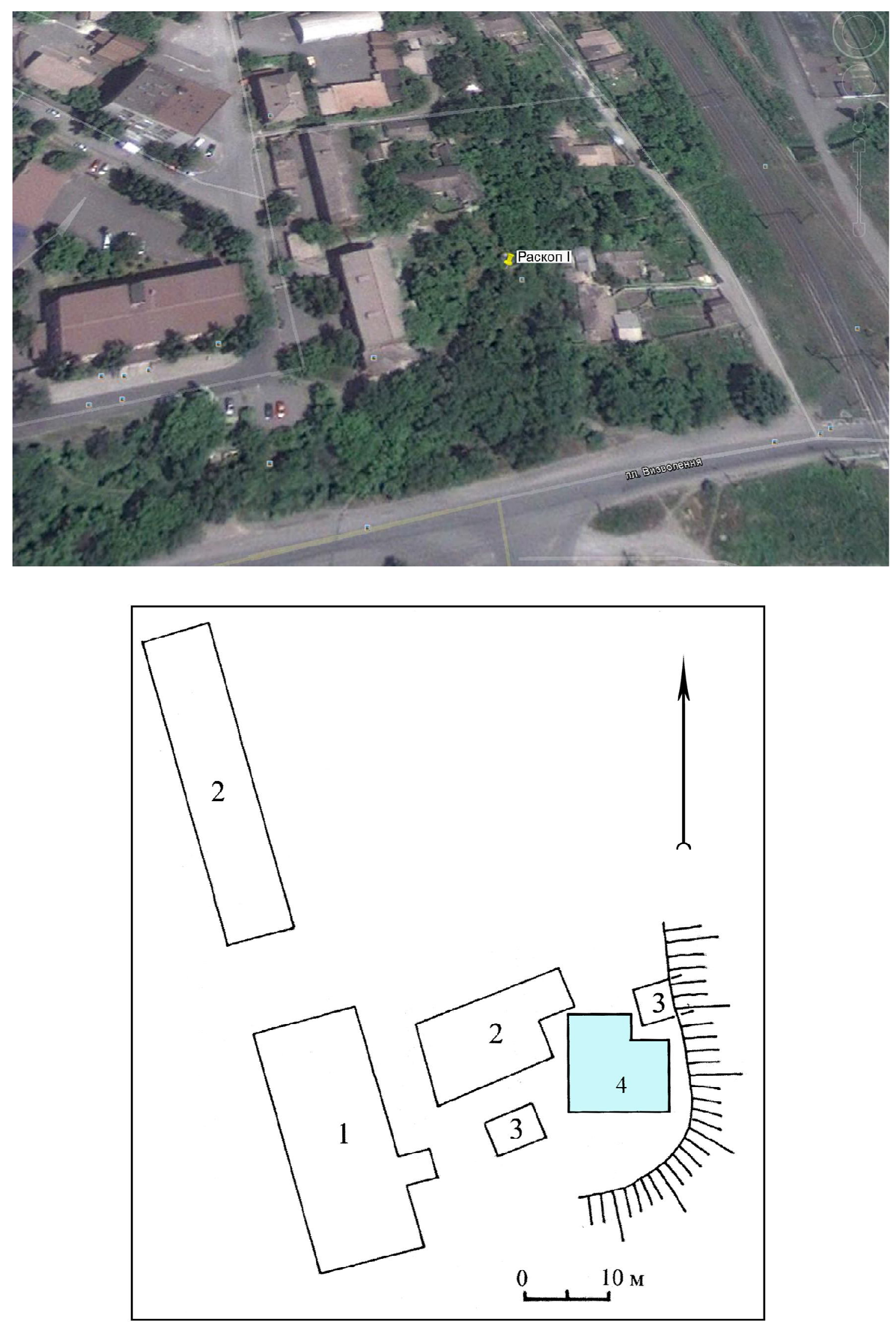

Рис. 1. Неолитическая стоянка Кальмиус. Ситуационный план: 1-3 - современные строения; 4 - раскоп I, 2014 г. 
Неолитический комплекс содержит разнообразные расщепленные кремни, изделия из песчаника и сланца, фрагменты керамики, кости животных.

Анализ керамического комплекса показывает его сложный состав. Основная часть аналогична образцам керамики нижне-донской культуры, при этом встречаются образцы азово-днепровской и сурской керамики [4; 8].

Коллекция кремневых изделий из раскопа 2012 г. обстоятельно проанализирована в статье Ю.Г. Коваля и С.М. Дегерменджи [7].

Целью настоящей заметки является анализ кремневой коллекции 2014 г., а также публикация изделий из «мягких» пород камня.

\section{Общая характеристика коллекции кремневых изделий 2014 года}

Кремневая коллекция из раскопа 2014 г. содержит 1187 предметов, преимущественно мелких сколов (табл. 1). В структуре коллекции доминируют мелкие сколы и фрагменты, орудия и их обломки. Немногочисленные нуклеусы представлены только остаточными формами.

Среди видов кремневого сырья визуально определяется качественный серый кремень мелового происхождения и, в минимальном количестве, низкосортный кремень аллювиального происхождения, в нескольких случаях - кремнистая порода из местных извест- няков третичного возраста. Ближайшие к стоянке источники качественного мелового кремня находятся в бассейне р. Сухие Ялы и в Южном Донбассе в бассейне р. Крынки на расстоянии 80 и 120 км.

\section{Анализ технологии первичного расщепления}

Первичное расщепление базировалось на утилизации объемных и плоских нуклеусов для пластин. Основой для реконструкции технологии первичного расщепления служат несколько остаточных нуклеусов, многочисленные пластины, трансформированные в той или иной степени служебные сколы.

Первоначальные размеры нуклеусов можно восстановить по целым пластинам без следов обработки или с минимальной обработкой. В коллекции 2014 г. сохранились три целые пластины с изогнутым перообразным окончанием и без следов вторичной обработки (рис. 2, 9-11). Длина пластин соответственно 87 мм, 65 мм и 56 мм. Длина наиболее крупного орудия из пластины (рис. 3, 46) составляет 88 мм; заготовка этого орудий не превышала в длину 100 мм.

Имеющиеся в коллекции немногочисленные нуклеусы предназначались для скалывания пластин и отщепов. Все нуклеусы представлены остаточными формами.

Кальмиус-2014. Структура коллекции неолитических кремневых изделий

\begin{tabular}{|r|l|r|r|}
\hline № & \multicolumn{1}{|c|}{ Категории изделий } & Количество & \multicolumn{1}{c|}{$\%$} \\
\hline 1 & Нуклеусы & 6 & 0,5 \\
\hline 2 & Ретушер-отбойник из отщепа & 1 & 0,1 \\
\hline 3 & Чешуйки (сколы до 10 мм) & 307 & 25,9 \\
\hline 4 & Отщепы 10-30 мм & 203 & 17,1 \\
\hline 5 & Отщепы свыше 30 мм & 9 & 0,8 \\
\hline 6 & Ребристые сколы & 5 & 0,5 \\
\hline 7 & Сколы с площадок & 8 & 0,7 \\
\hline 8 & Сколы формирования бифасов & 19 & 1,6 \\
\hline 9 & Вентральные сколы & 4 & 0,3 \\
\hline 10 & Пластины и их фрагменты без ретуши & 208 & 17,5 \\
\hline 11 & Изделия с вторичной обработкой & 253 & 21,3 \\
\hline 12 & Недиагностичные обломки орудий раз- & 59 & 4,9 \\
& ных типов & & 1,5 \\
\hline 13 & Отщепы с ретушью & 87 & 7,3 \\
\hline 14 & Обожженные кремни & 1187 & 100,0 \\
\hline
\end{tabular}



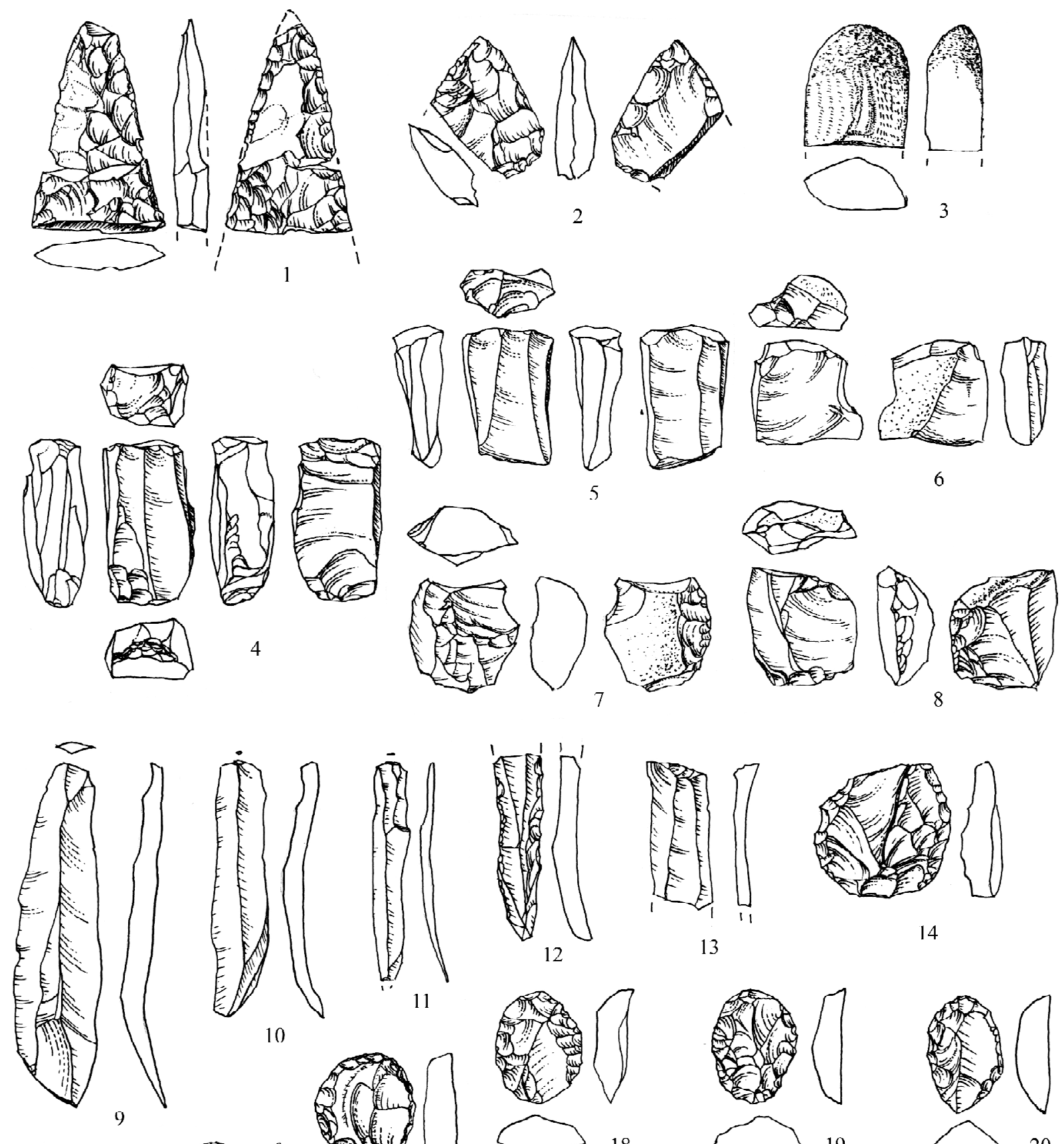

12

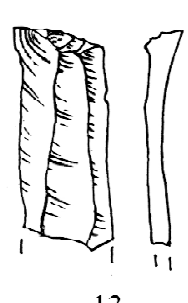

13

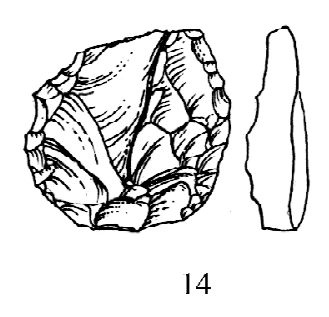

10
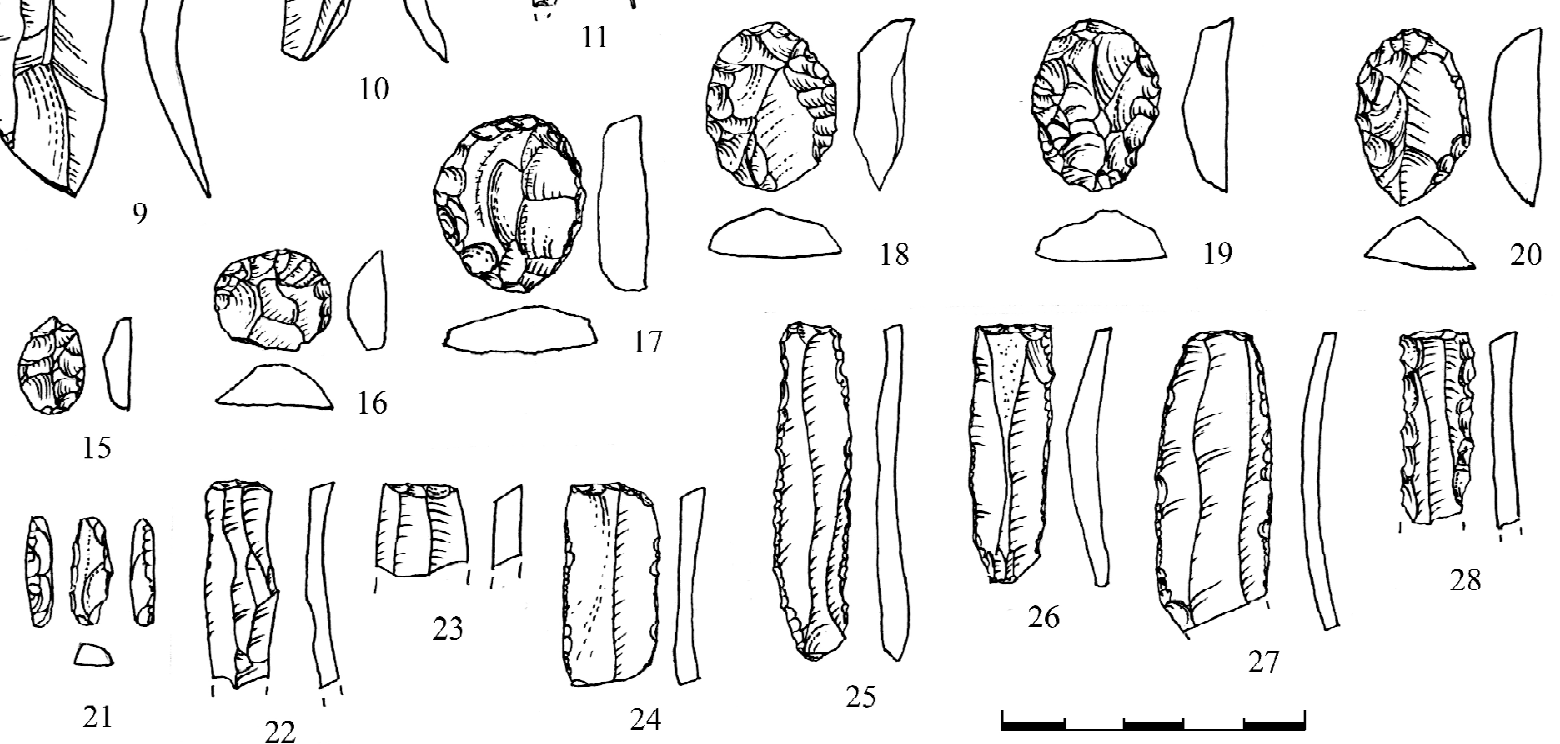

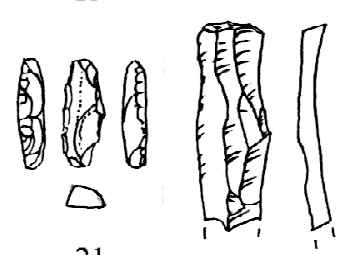

22

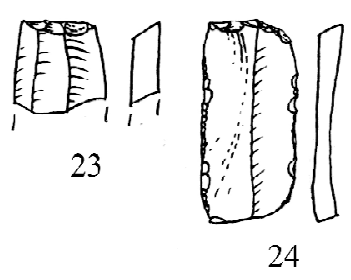

28

Рис. 2. Неолитическая стоянка Кальмиус. Кремневые изделия 


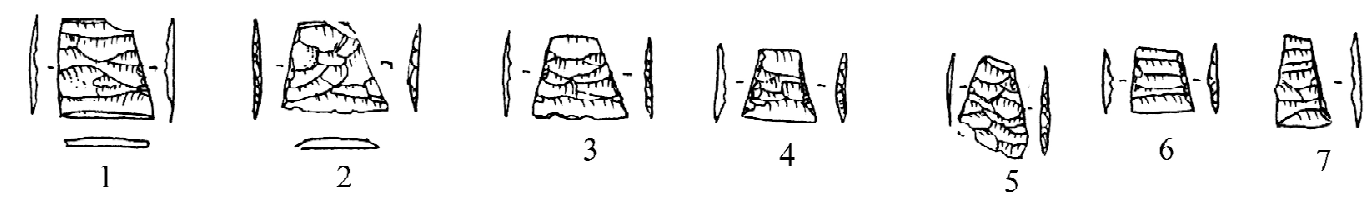

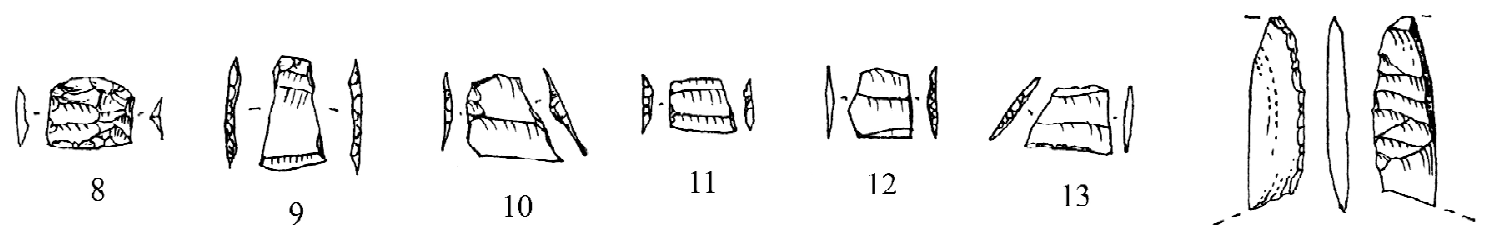

14

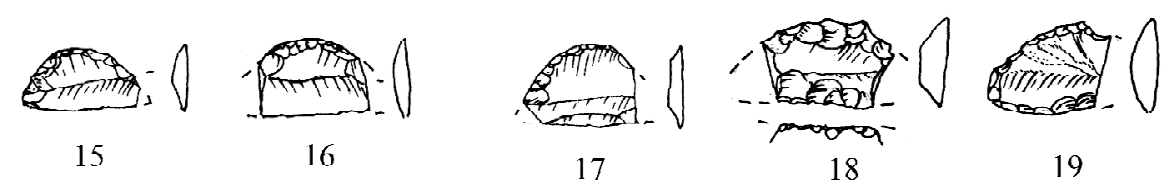
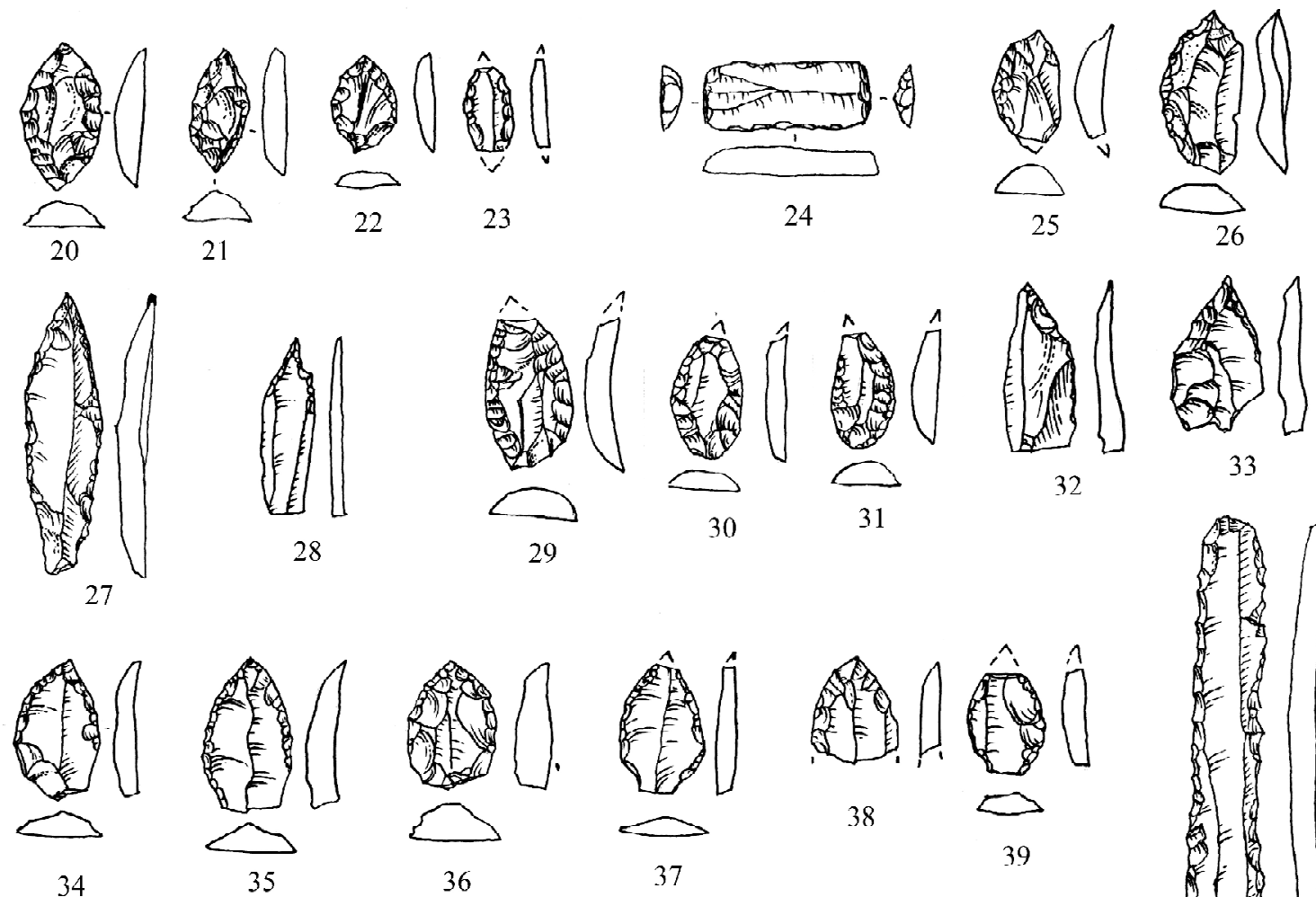

34
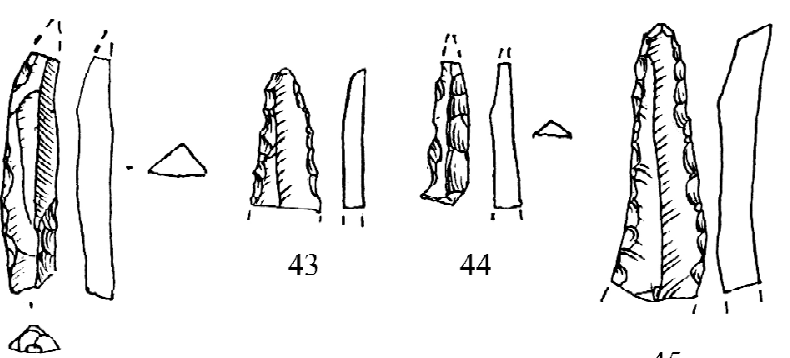

42

45

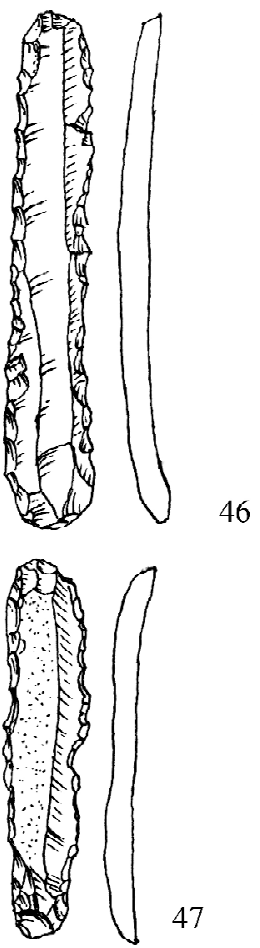

Рис. 3. Неолитическая стоянка Кальмиус. Кремневые изделия 
Остаточные формы нуклеусов отражают два типа редукции нуклеусов. Первый, классический, связан с расщеплением одноплощадочных призматических нуклеусов, с карандашевидной формой, на последней стадии эксплуатации. Имеющиеся в коллекции продольные сколы с нуклеусов, захватывающие часть боковой поверхности и основание со сходящейся огранкой, относятся к классическому типу редукции. С оживлением этих нуклеусов, видимо, связаны классические сколы с площадок («таблетки») (8 шт.), ребристые сколы (5 шт.).

Судя по сохранившему остаточному нуклеусу (рис. 2, 4), после исчерпания возможности призматического скалывания с одной площадки нуклеус раскалывался вдоль либо с него скалывали крупные боковые участки, образующие плоские поверхности. Дальнейшее расщепление приводило к формированию плоскостного рабочего фронта для пластин; нуклеус приобретал брусковидные очертания (рис. 2, 5). Похожий тип скалывания пластин с плоского рабочего фронта нуклеусов описан Е.Ю. Гирей и В.М. Лозовским [3].

Второй, специфический тип редукции, был связан со скалывание отщепов и коротких пластин с нуклеусов, изготовленных из первичных сколов (рис. 2, 6-8). На последней стадии эксплуатации нуклеусы приобретали вид небольших кубических ядрищ. Сработанные до предела уплощенные нуклеусы для отщепов переоформлялись в скребки (рис. 2, 7-8).

Основную роль играло скалывание пластин. Строгой корреляции между шириной пластины и ее длиной нет. Преобладают пластины с устойчивой двух-трехскатной огранкой и типичным профилем с загнутым дистальным окончанием. Форма и пропорции этих пластин являются типичными для такого типа нуклеусного расщепления [2].

Таким образом, первичное расщепление было ориентировано на получение средних по величине отжимных пластинчатых заготовок, в пределах 50-100 мм. Примечательно, что при наличии в коллекции серии микропластинок нет орудий их них. Видимо, микропластинки были служебными сколами, необходимыми для поддержания параллельной огранки рабочего фронта.

Инструменты для расщепления кремня представлены небольшим песчаниковым ретушером-отбойником (рис. 2, 3) и небольшим кремневым ретушером.

\section{Изделия с вторичной обработкой}

Среди изделий с вторичной обработкой доминируют три группы орудий - ретушированные орудия из целых пластин, короткие скребки из отщепов и пластин, геометрические и «негеометрические микролиты». Орудия с двусторонней обработкой статистически выражены слабо. В приведенном ниже описании авторы старались отразить естественные морфологические связи между изделиями, возможно, в ущерб их строгой типологической дифференциации (табл. 2).

Культурно-специфическое ядро коллекции кремневых изделий образует небольшая серия геометрических микролитов, два бифасиальных наконечника и ряд особых типов «негеометрических микролитов».

Первый из наконечников - небольших размеров, атипичный, незаконченный (рис. 2, 2). Второй представлен двумя обожженными фрагментами (рис. 2, 1). Форма целого нако-

Кальмиус-14. Кремневые изделия с вторичной обработкой

Таблица 2

\begin{tabular}{|c|l|c|c|}
\hline № & \multicolumn{1}{|c|}{ Группы орудий } & Количество & $\%$ \\
\hline 1 & Наконечники с двусторонней обработкой & 2 & 0,8 \\
\hline 2 & Геометрические микролиты & 20 & 8,0 \\
\hline 3 & «Частичные геометрические микролиты» & 3 & 1,2 \\
\hline 4 & $\begin{array}{l}\text { Пластины с ретушью (продольная ретушь } \\
\text { + различные усечения), фрагменты }\end{array}$ & 81 & 32,0 \\
\hline 5 & Острия разных типов, фрагменты & $11+3$ & 5,5 \\
\hline 6 & Скребки разных типов, фрагменты & $93+23$ & 45,8 \\
\hline 7 & «Негеометрические микролиты» Всего & 253 & 6,7 \\
\hline \multicolumn{3}{|l|}{ Всы } \\
\hline
\end{tabular}


нечника, скорее всего, была листовидной. О производстве бифасиальных наконечников (возможно, топоров) на месте неолитического поселка свидетельствуют специфические сколы вторичного утончения (19 шт.).

Группа микролитов включает 20 изделий. Типологический набор микролитов в целом характерен для неолитических культур юга Восточной Европы. Типологическое ядро микролитов составляют трапеции со струганной спинкой. Всего их 7 шт. Среди них присутствуют средневысокие асимметричные (рис. 3, 1-2) и средневысокие симметричные (рис. 3, 3-4, 6) трапеции. Выделяется также одна высокая трапеция с узким корпусом (рис. 3, 7). Все трапеции выполнены из тонких пластин. Вторичные площадки утончения гладкие и ретушированные со стороны спинки заготовки. В ряде случаев вторичная площадка устранена сколами с брюшка вместе с базальной частью негативов вторичных «строгающих» сколов. Этот прием обеспечил плавный рельеф дорсальной поверхности микролитов. Крупный фрагмент трапеции со струганной спинкой (рис. 3,14 ) имеет ретушированную вторичную площадку, обработанную «на брюшко».

Небольшая серия аналогичных трапеций со струганной спинкой происходит из Мариупольского могильника. Наиболее выразительные из них названы «клинами міролітичного виробництва» $[9$, рис. 94,96$]$.

Два сечения пластин имеют следы вторичного утончения продольного ребра.

Такую же небольшую (7 шт.) выразительную серию составляют сегменты (рис. 3 , 15-19). Практически все они в той или иной степени фрагментированы. Как правило, имеют обработанную выпуклую сторону и необработанное прямое основание. Особое место в этой серии занимает «сегмент со струганной спинкой» (рис. 3, 8). Выпуклый край микролита обработан сплошной мелкой ретушью, также как и прямое основание. Ретушь утончения нанесена с одной из вторичных площадок на заключительной стадии обработки для понижения высоты рельефа спинки.

Классические трапеции относятся к высоким симметричным (рис. 3,9$)$ и средневысоким асимметричным (рис. 3, 10-14) формам.
В категорию микролитов входит классический прямоугольник (рис. 3, 24) из двускатной пластины. Оба конца прямоугольника усечены отвесной ретушью.

Представленные в коллекции геометрические микролиты отражают достаточно сложный репертуар приемов вторичной обработки, связанный с индивидуальной подгонкой каждого образца в наборное лезвие или каркас наконечника. Вариативность форм и приемов обработки микролитов свидетельствует о том, что это был массовый расходный материал, легко адаптируемый под нужный формат лезвийной кромки.

Промежуточное положение между трапециями фрагментами косо усеченных пластин занимают так называемые «частичные трапеции» - изделия из сечений пластин, у которых один край ретуширован, второй является торцом слома без следов ретуши (3 шт.). По форме эти изделия - обычные трапеции, но с одним неретушированным краем (рис. 3, 12-13). В равной степени это могут быть и обломки пластин с косым или поперечным усечением.

Серийно представлены пластины с различным типом усечения концов при помощи ретуши. Часть из них морфологически напоминает концевые скребки. Аргументом в пользу атрибуции пластин с поперечным усечением служит относительно ровный (не выпуклый) торцовый конец, крутой, обрубающий характер ретуши.

Среди пластин с поперечным усечением выделяются орудия с ретушированными продольными краями (13 шт.) и без ретуши (5 шт.). Поперечно усеченные торцы, как правило, прямые, без следов забитости и сработанности, то есть выполняли аккомодационные цели (рис. 2, 23, 26, 28). Продольный профиль этих орудий изогнут слабо. Стандартной процедурой было отсечение изогнутых «хвостов» у целых пластин и ретуширование образовавшегося торца. В этом контексте тронкирование - прием ограничения корпуса пластины по длине на наиболее выпрямленном участке.

Косое усечение пластин (4 шт.) по форме близко косым остриям (рис. 2,$13 ; 3,40-41$ ).

Пластины с косо-овальным усечением (13 шт.) также изготовлены из пластин средней 
величины (рис. 2, 24-25, 27). Обработанный участок часто придает изделиям вид обушка. Обломки концов этих изделий трудноотличимы от обломков микролитов-сегментов.

Небольшая серия полностью сохранившихся ретушированных пластин (6 шт.), видимо, показывает стандартный тип орудий из пластин (рис. 3, 46-47). Ретушь на краях целых пластин с фасетками разных размеров придает краям зубчатый контур. Кромки интенсивно сработаны. Дистальные концы овальных очертаний также интенсивно сработаны. Они напоминают сработанные лезвия узких концевых скребков. Возможно, к этому типу орудий относятся фрагменты ретушированных пластин (2 шт.) с параболическим ретушированным окончанием.

Базальные части (17 шт.) и сечения (22 шт.) пластин с ретушью являются фоновой находкой. Практически все они имеют ширину в пределах 8-12 мм.

Все же основное количество пластин и их фрагментов (208 шт.) не имеют ретуши и явных следов сработанности.

Небольшую серию образуют остриясверла (6 шт.), отличающиеся удлиненнотреугольным массивным корпусом и треугольным поперечным сечением (рис. 2, 12; $3,42-44)$. Все орудий обработаны крутой ретушью. Продольные края и острие интенсивно сработаны.

Острие на пластине (рис. 3,27$)$ в своей острийной части на дорсальной стороне имеет след псевдорезцого скола, возможно, возникшего от удара о твердую поверхность. К этому типу орудий относятся также 3 фрагмента острийных участков.

Единственным экземпляром представлена проколка на пластине (рис. 3, 28).

Ограниченным количеством представлены также острие на отщепе (рис. 3, 33), косое острие на пластине (рис. 3, 32).

Класс скребков наиболее многочисленный и представлен преимущественно скребками на отщепах, что определило их размеры и пропорции. Скребки вместе с фрагментами $(93+23$ шт.) составляют почти половину всего орудийного инвентаря. Для производства скребков использовались преимущественно отщепы размерами до 40-45 мм, однако значительная часть скребков, если не основная, на стадии интенсивного использования существенно уменьшалась в размерах за счет неоднократного оживления лезвийных кромок. Пластинчатые заготовки для производства скребков практически не использовались, поэтому скребки концевых форм как таковые в коллекции 2014 г. не выделяются, с учетом оговорки о схожести «концевых скребков» с тронкированными пластинами. Скребки, в целом, отличаются небольшими размерами.

Овальные (3 шт.) и округло-овальные (6 шт.) скребки с полной круговой обработкой (рис. 2, 16-20) вполне соответствуют классическим стандартам. Этой группе скребков морфологически примыкают (11 шт.) и округло-овальные (10 шт.) скребки с частичной круговой обработкой. Как правило, у этих скребков лезвия разомкнуты на месте ударных площадок сколов-заготовок. Заготовкой служили отщепы.

Овальные микроскребки (7 шт.) отличаются неустойчивыми очертаниями при наличии признаков интенсивной сработанности. Практически все являются остаточными формами (рис. 2, 15, 21). Очевидно увеличение морфологической вариабельности по мере изнашивания скребков.

Конвергентно-стрельчатые скребки (14 шт.) могут быть описаны как миниатюрные конвергентные скребла, миниатюрные простые и асимметричные остроконечники, асимметричные острия, а также другими категориями, поскольку обладают признаками всех этих типов орудий (рис. 3, 34-39). Изготовлены из отщепов и пластин. Этот условный тип орудий нуждается в дальнейшей дифференциации. Часть изделий - явные остаточные формы со значительным «редукционным возрастом».

Боковые-угловые скребки на отщепах (17 шт.) характеризуются наличием одного протяженного выпуклого лезвия, расположенного на продольном крае скола. Необработанный край не имеет устойчивой морфологии. В некоторых случаях окончание лезвийной кромки, совпадающее с концом отщепа, дополнительно подработано. Такие скребки достаточно просто модифицировать в конвергентно-стрельчатые скребки или в листовидные микроострия.

Фрагментами рабочих участков (4 шт.) представлены «скребки с носиком». Все из- 
готовлены из пластин средней величины. Морфологическая особенность этих орудий - наличие округлого выступа в средней части рабочего лезвия. В трех случаях рабочий край интенсивно сработан; на выступах образовался ступенчатый рельеф с широкой интенсивно забитой и заглаженной кромкой. Высота выступа до 3-5 мм.

Особое место занимают округлые в плане скребки, изготовленные из сколов оживления площадок призматических нуклеусов (4 шт.). Разумеется, сколов оживления площадок и скребков из них в коллекции больше, но ясные признаки служебных сколов сохранились только на этих образцах (рис. 2, 14). Ретушь вторичной обработки не устранила характерный ступенчатый рельеф площадки от встречных сколов и поперечные негативы целевых пластинчатых сколов.

Атипичных скребков всего 19 шт.

В культурном слое найдены также 23 фрагмента скребков.

К специфическим типам изделий относится группа изделий, которые условно можно назвать «негеометрические микролиты». Среди них особое место занимают листовидные микроострия, входящие в сопряженную группу типов скребковидных изделий по форме и характеру обработки. Уверенно к этому типу можно отнести 7 изделий. Они имеют широкий неправильно листовидный корпус с двумя полярными остриями (рис. 3, 20-23). Основой двух орудий послужили отщепы, остальные изготовлены из пластинчатых сколов. Возможно, последовательность изменения формы этих изделий была отличной в зависимости от характера заготовки. Теоретически листовидные микроострия могут быть редукционной формой острий на пластинах, a также результатом предельного истощения боковых скребков. К появлению листовидных микроострий могло привести переоформление конвергентно-стрельчатых скребков.

Представлены также специфические миниатюрные изделия, по форме близкие асимметричным остроконечникам среднего палеолита (7 шт.). Эти изделия (рис. 3, 29-31) относительно тонкие, тщательно ретушированные по всему периметру. Корпус оформлен как у овальных скребков, но один из концов в плане образует отчетливое скошенное острие.
Сегментовидные острия (3 шт.) изготовлены из пластин (рис. 3, 25-26), по форме близки микролитам-сегментам, но оба заостренных конца специально выделены ретушью, заходящей на «основание» сегмента - необработанный край платины-заготовки. В отличие от сегментов, изделия достаточно массивны. У орудий этого типа выпуклый скребковидный край сочетается с двумя асимметричными острийными участками.

В коллекции полностью отсутствуют резцы; признаки резцовой техники, скорее всего, связаны с контрударным эффектом деформации вкладышей метательного оружия.

В целом, кремневая индустрия неолитического времени из поселения Кальмиус является среднепластинчатой, основанной на пластинчатых и отщеповых заготовках. Основу орудийного ансамбля составляли ретушированные пластины и короткие скребки различных типов, изготовленные преимущественно из отщепов. Доля геометрических микролитов около 10 \%. Ядро коллекции геометрических микролитов составляют трапеции со струганной спинкой и сегменты. Весьма специфичны «негеометрические микролиты». Резцы не отмечены. Концевые скребки типологически не выражены.

\section{Сравнительный анализ кремневой индустрии}

Публикуемая кремневая индустрия по основным технико-типологическим параметрам сопоставима прежде всего с неолитическими стоянками Нижнего Дона, расположенными у станицы Раздорской $[17 ; 18]$. Отдельные элементы кремневого комплекса близки стоянкам среднего течения Северского Донца, например, комплексу стоянки Туба 1 [5, рис. 117].

Интересно сопоставление с материалами Мариупольского неолитического могильника. Как известно, при раскопках могильника в 1930 г. Н.Е. Макаренко была собрана коллекция кремней, происходящих из погребений и грунтовой засыпки $[9$, с. 34-38]. Из могил происходят около 150 кремней, в заполнении найдено более 20 кремней. В могильник попали исключительно отобранные образцы, которые в двух случаях (погребения LXXXIV и LXXXIX) сохранились в форме индивидуаль- 
ных ранцевых наборов. Основная часть кремневых изделий из Мариупольского могильника полностью сопоставима с изделиями из стоянки Кальмиус. Это наконечники треугольной и листовидной формы с двусторонней обработкой, трапеции (в том числе со струганной спинкой), ретушированные пластины, округлые скребки, призматические нуклеусы, пластины с поперечным усечением и ретушированным краем, острия на пластинах. Примечательно, что предметы этой серии из могильника существенно крупнее предметов из стоянки. Артефакты из могильника и стоянки сделаны из похожего кремневого сырья. Особое внимание следует обратить на тонкую шлифованную прямоугольную плитку размерами $195 \times 90$ мм из погребения XXX [9, рис. 34]. Плитка близка уникальным изделиям из стояночного комплекса. В погребении плитка сопровождается каменным терочником. На груди погребенного в могиле СXXIII лежал колчанный набор с наконечниками стрел из трапеций (не менее пяти штук) [9, рис. 89]; они относятся к тем же типам, что и трапеции из неолитического слоя стоянки Кальмиус. Таким образом, сравнительный анализ кремневых изделий могильника и стоянки в целом свидетельствует в пользу культурной однородности этих комплексов.

Вместе с тем один тип изделий из могильника не представлен на стоянке. Речь идет о концевых скребках средних размеров с выпуклым лезвием [9, рис. 16, 50, 69]. Возможно, присутствие концевых скребков и крупной пластины (длиной 164 мм) отражает более широкую хронологию могильника по отношению к участкам поселения, вскрытым новейшими раскопками.

\section{Опыт редукционного анализа кремневого комплекса}

Важнейшим лимитирующим фактором, определявшим внешние параметры комплекса кремневых изделий, была удаленность от стоянки основных геологических источников кремневого сырья. Принято считать, что в радиусе 100-150 км образовывалась зона потребления преимущественно местного кремневого сырья [22, fig. 1]. Расстояние до 100 км между стоянкой и геологическими источни- ками кремня не является критическим с точки зрения сырьевого обеспечения. Вместе с тем кремневый комплекс неолитической стоянки Кальмиус демонстрирует предельную степень интенсивности переработки кремневого сырья. Максимальное истощение нуклеусов, высокий процент фрагментации и подправки орудий, высокий индекс фрагментации пластин, выраженный микролитизм орудий позволяют уверенно диагностировать интенсивный характер сырьевой стратегии в одной из его крайних форм.

О весьма значительной степени переработки каменного сырья свидетельствует весовая характеристика отдельных групп инвентаря. Вся собранная в пределах раскопа 2014 г. коллекция кремневых предметов весит 1703 кг, в том числе:

- отщепы разных типов и чешуйки 662 г;

- нуклеусы и их фрагменты - 82 г;

- кремневый ретушер - 7 г;

- пластины без ретуши - 220 г;

- орудия на пластинах - 236 г;

- двусторонний наконечник - 4 г;

- обломки орудий - 48 г;

- скребки - 392 г;

- обломки скребков - 50 г.

Орудия и их фрагменты суммарно весят 737 г, то есть 43,3 \% всех кремней коллекции 2014 года. Это беспрецедентно большая весовая фракция орудий в кремневом инвентаре стоянки каменного века.

Ярким показателем высокой степени интенсивности переработки кремневого сырья являются параметры сколов. Подавляющая часть отщепов - это чешуйки, то есть сколы размерами до 10 мм (307 шт.) и отщепы размерами до 30 мм (205 шт.). Более крупные отщепы (до 50-70 мм) единичны - их всего 9 шт. Очевидно, что практически все отщепы крупнее 30 мм трансформировались в скребки разных типов. То же касается и пластин. Процент сколов с первичной коркой не превышает $12 \%$. Таким образом, до предела утилизировались практически все нуклеусы, отщепы и пластины.

Наши наблюдения совпадают с оценкой степени редукции кремневого комплекса из раскопа 2012 года. По определению авторов публикации, «дефицит сырья неизбежно накла- 
дывал отпечаток на весь облик кремневого комплекса неолитического слоя пос. Кальмиус (общий микролитизм индустрии, глубокая переработка каменного материала, очень высокий процент орудий)» [7, с. 86].

В археологии каменного века в рамках теории интенсивности заселения принят постулат о зависимости структуры каменной индустрии от глубины переработки каменного сырья $[20,21]$. Неоднократная подправка орудий, максимальное использование всех пригодных сколов в условиях дефицита каменного сырья закономерно приводила к микролитизации инвентаря, появлению новых типов орудий.

Реконструируемый начальный формат индустрии строится на отжимной пластине средней величины. Стандартной выглядит пластина длиной 100 мм, шириной 15 мм, с участком со слабым искривлением длиной 80 мм. Видимо, на стоянку поступали небольшие и средние по размеру нуклеусы (со средней высотой фронта до 100-120 мм), заготовки нуклеусов и предварительно обработанные кремневые конкреции. Целые пластины из Мариупольского могильника имеют размеры $90,92,122,140$ и 164 мм.

Документированный материалами поселения Кальмиус классический тренд редукции неолитических нуклеусов отличается от порядка расщепления призматических нуклеусов донецкой мезо-неолитической культуры, которые на последней стадии утилизации были рассчитаны на массовое получение отжимных микропластинок и трансформировались в хорошо известные карандашевидные формы, которые дальше практически не расщеплялись. В анализируемой коллекции карандашевидные нуклеусы были промежуточной стадией трансформации нуклеусов, которая заканчивалась образованием нуклеусов с плоским рабочим фронтом и мелкими кубовидными ядрищами. Размеры негативов на них не превышают 20 мм.

В ходе редукции изделий из отщепов происходило закономерное уменьшение их размеров; параллельно росло число орудий со сходящимися лезвиями (конвергентные скребла и остроконечники). Этот тип редукции детально описан Г. Дибблом [19].

Именно в таком контексте следует рассматривать совокупность скребков неолити- ческого комплекса Кальмиус. Скребки конвергентно-стрельчатой формы логически дополняются миниатюрными орудиями листовидной формы, своеобразными стрельчатыми скребками.

Значительной серией представлены миниатюрные овальные скребки, морфологически дополняющие серию более крупных округлых и атипичных скребков с полной или частичной круговой обработкой.

Возможно, заключительной редукционной формой крупных острий являются миниатюрные асимметрические острия, по форме близкие асимметричным остроконечникам киик-кибинской индустрии Крыма.

Таким образом, есть веские основания считать основную часть негеометрических микролитов комплекса особым образом редукционными типами кремневого инвентаря. Заметна тенденция к нарастанию типологической вариативности кремневого комплекса по мере увеличения интенсивности переработки каменного сырья. Типологическое разнообразие увеличивается в первую очередь за счет негеометрического микроинвентаря.

\section{Изделия из «мягких» пород камня}

В культурном слое найдены также изделия из «мягких» пород камня - сланца, неплотного песчаника. Этот материал поступал на поселение «со стороны», так как вблизи памятника нет источников таких пород.

Группа включает крупное изделие типа «утюжка», две крупные шлифованные плитки неправильной овальной формы, обломки шлифованных плиток, фрагмент небольшого ретушера-отбойника.

Наибольший интерес представляет крупный предмет из желтовато-серого мелкозернистого песчаника (рис. 4, 1), входящий в широкий круг «поперечно-желобчатых изделий» каменного века - эпохи раннего металла [13]. Наиболее полная на сегодняшний день сводка «утюжков» Евразии включает около 500 образцов [16]. Особенности морфологии способствовали появлению различных наименований с нейтральным или выраженным функциональным контекстом. Изделия этого класса часто называют «утюжками», «желобчатыми 
абразивами», «челноками», «желобчатыми предметами», «выпрямителями древков стрел» и т. д. [14]. Существующие морфологические классификации существенно различаются между собой. Также нет устоявшегося мнения и по поводу их функций. В последнее время широко распространилось мнение о преимущественно сакральном значении этой группы предметов [11; 15]. Очевидно, обладатель «утюжка» был вовлечен в разнообразные обряды и церемонии в рамках всей социальной группы. Примечательно, что почти половина «утюжков» (45 \%) преднамеренно разбивалась в древности.
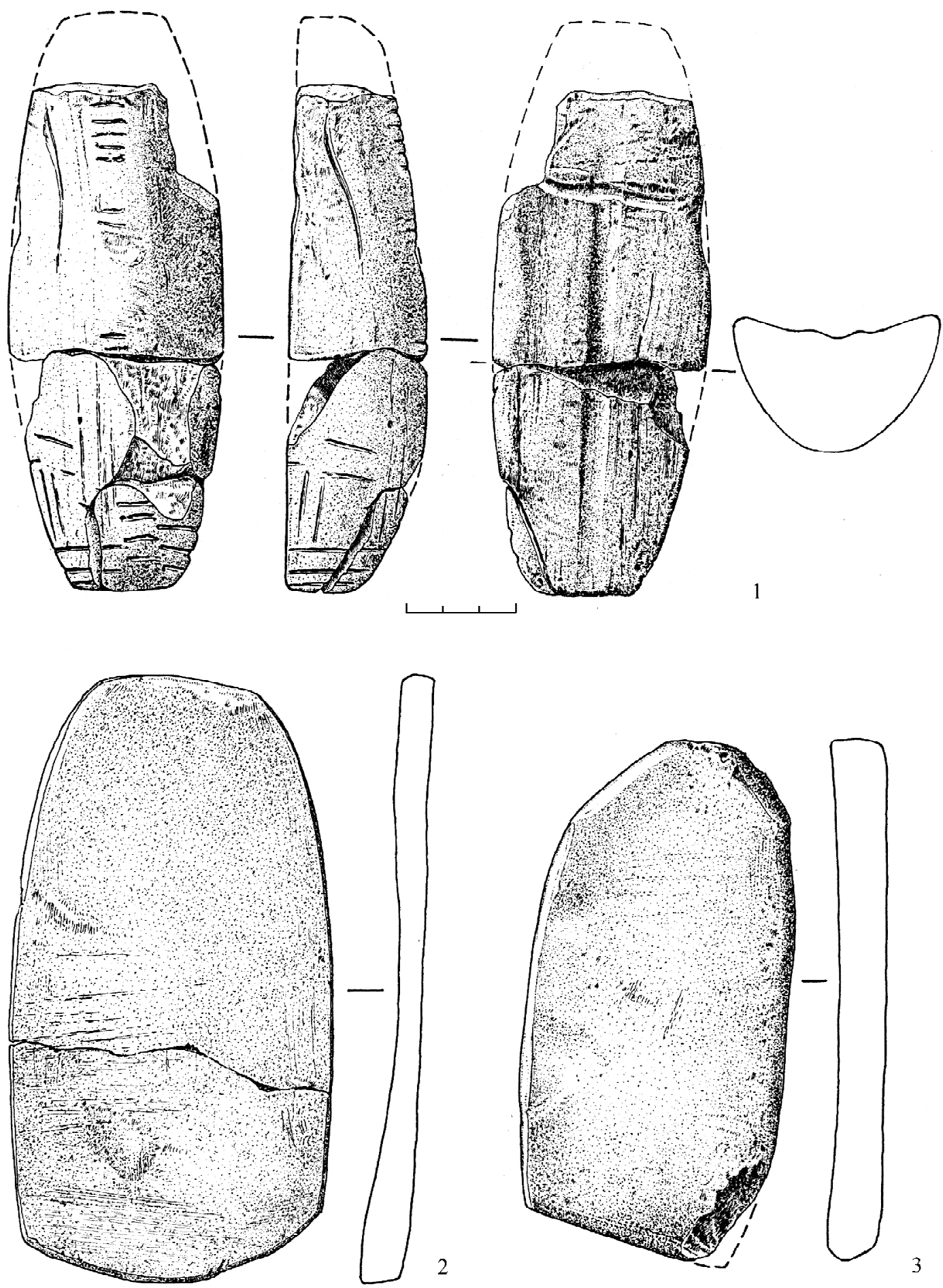

3

Рис. 4. Неолитическая стоянка Кальмиус. Изделия из «мягких» пород камня 
Экземпляр из поселения Кальмиус удалось реставрировать из нескольких фрагментов, залегавших на некотором удалении друг от друга. Размеры $137 \times 58 \times 37$ мм. Реконструируемая длина целого изделия - 155 мм. Изделие имеет вид удлиненного бруска бочкообразной формы, рассеченного надвое по продольной плоскости. Поперечное сечение выпукло-вогнутое. Нижняя рабочая поверхность с вогнутым сечением имеет проточенный желобок по продольной оси. Желобок не является сквозным. Канал желобка полуовальный, проходит по осевой линии. На выпуклой тыльной стороне вдоль ребра проточены неглубокие короткие желобки, образующие неширокую (до 15-17 мм) декоративную продольную полосу с нерегулярными поперечными насечками. На одном из концов изделия короткие поперечные желобки-насечки нанесены на боковые участки изделия, придавая этому участку неглубокий рифленый рельеф.

При общей конструкции в виде удлиненного плоско-выпуклого в сечении предмета эти изделия имеют существенные отличия в деталях. Типы этих изделий не образуют устойчивых культурно-хронологических или территориальных кластров и в небольшом количестве встречаются в разновременных памятниках Днепро-Донского междуречья. В регионах, окружающих Северное Приазовье, они известны в неолитических комплексах Старица XVIII на Северском Донце [1]. На неолитических памятниках Северского Донца встречены также абразивы различной формы, фигурное изделие из сланца [10]. На Дону известна литейная форма клиновидного тесла, вырезанная на плоской стороне более раннего, видимо, «утюжка» из талькового сланца с двумя поперечными желобами [5].

Орнаментальная полоса из ряда прямых насечек определяет круг аналогий «поперечно-желобчатому изделию» из стоянки Кальмиус. В ряде случаев тот же орнаментальный мотив оформлен в виде «лесенки» - полосы поперечных насечек, ограниченных длинными продольными линиями. Нет нужды говорить о широком распространении такого декоративного элемента на неолитической керамике. На поперечно-желобчатых изделиях из мягких пород камня резной декор чаще всего локализуется на самых выступающих поверхностях по выпуклому ребру. Аналогичный предмет найден на стоянке Козинцы в Поднепровье. Здесь обнаружен фрагмент плоско-выпуклого «челнока» овальной формы с одним поперечным желобом и продольной орнаментированной лентой по ребру [23, taf. 16, 16]. В культурном слое стоянки Раздорская 2 найдены различные «утюжки», в том числе вытянуто-овальный в плане экземпляр с декоративной полосой в виде «лесенки» вдоль продольного ребра [18, рис. 49, 4]. Во всех случаях поперечные насечки проявляют определенную группировку скученных и разреженных элементов. Возможно, это отражает числовую ритмику, имеющую определенную семантическую нагрузку.

Две полностью сохранившиеся крупные шлифованные плитки из мелкозернистого песчаника дают представление об изделиях, возможно, приспособленных для тонкого растирания небольшой массы каких-то мягких веществ. Плитки имеют вид широких пластин со слегка выпуклыми продольными краями и грубо округленными концами. Размеры первой плитки $164 \times 87 \times 6$ мм (см.: рис. 4,2$)$, второй $-140 \times 70 \times 12$ мм (см.: рис. 4,3$)$. Основу, видимо, составляли естественные тонкие плитки этого камня. Обработанные поверхности плоские, со слегка вогнутым профилем, охватывают всю поверхность плиток. Боковые участки и округленные торцы также пришлифованы. На одном экземпляре шлифовка двусторонняя (рис. 4, 2). Эта плитка весьма тонкая и вряд ли бы выдержала значительную физическую нагрузку. Функциональное назначение этих тщательно изготовленных предметов во многом остается неясным. В одном из погребений Мариупольского могильника вместе с тонкой шлифованной каменной плиткой был помещен камень с плоской рабочей поверхностью, что позволяет предполагать использование этого набора для растирания неплотных органических или минеральных материалов. В типологическом плане шлифованные плитки из могильника и стоянки относятся к одному классу изделий.

Найденные в неолитическом культурном слое два фрагмента тонких шлифованных плиток из мелкозернистого песчаника являются частью подобных изделий. Один из фрагментов плитки из мелкозернистого бурого песча- 
ника имеет толщину 7 мм, округлый тщательно обработанный край, параллельные тонко шлифованные поверхности. Второй фрагмент плитки сизого песчаника толщиной 5-7 мм хорошо отшлифован с одной стороны и пришлифован с другой. Вдоль одного из краев сохранились следы технологического слегка искривленного пропиленного паза, который определил место слома заготовки при ее форматировании; торец слома и продольный борт паза зашлифованы на завершающей стадии обработки. Глубина паза около 1 мм, он имеет параболический профиль, средний между V- и U-образным сечением.

Близкие аналогии фрагментам шлифованных плиток известны в материалах стоянки Раздорская 2 на Нижнем Дону [17]. Часть тонких шлифованных плиток из донской стоянки, трактуемых автором раскопок в качестве «орнаментированных плиток» $[18$, рис. 48 , 7-10], была расколота по глубоким прорезанным линиям. Возможно, они имели не только декоративное, но и технологическое значение. Судя по огромному количеству обломков, отщепов и готовых изделий $(30,8 \%$ всей коллекции каменных изделий), здесь было хорошо налажено производство орудий и украшений из местного сланца и песчаника [18, с. 90].

Изделия из «мягких» пород камня (кроме ретушера-отбойника) не могут считаться рядовыми находками. Безусловно, они были включены в элитарную культуру социума. Из этого следует особый характер поселения на правом берегу реки, на котором, весьма вероятно, проживали представители социальной и культовой верхушки общины.

\section{Выводы}

Стоянка Кальмиус располагается на берегу крупной степной реки. Видимо, в древности в низовьях реки существовала благоприятная природно-климатическая обстановка, комфортная для проживания крупной неолитической общины.

Кремневая коллекция местонахождения не содержит инокультурных примесей и отражает относительно короткий в хронологическом смысле эпизод заселения. Отсутствие местной сырьевой базы обусловило глубокую утилизацию принесенного каменного сырья.
Технологический облик кремневой индустрии соответствует классической схеме неолита и энеолита, основанной на регулярном расщеплении нуклеусов для пластин и производстве бифасов разных типов. Основу орудийного набора составляют ретушированные изделия из пластин, скребки, геометрические микролиты. Выразительны трапеции со струганной спинкой. Для кремневой индустрии характерна ярко выраженная микролитоидность. Культурную специфику определяют остриясверла, пластины с косым или поперечным усечением, отдельные типы геометрических и негеометрических микролитов, миниатюрные острия, стрельчатые скребки. Концевые скребки и резцы не характерны. Особую категорию инвентаря составляют изделия из «мягких» пород камня.

В культурном плане наиболее обоснованные параллели каменному инвентарю прослеживаются среди неолитических памятников Нижнего Дона. Трапеции со струганной спинкой указывают на относительно поздний в пределах неолита возраст. Керамический комплекс отражает более сложную картину с участием азово-днепровского и сурского компонентов при доминировании нижне-донского. Строгое таксономическое значение стоянки Кальмиус в плеяде неолитических культур и типов памятников юга Восточной Европы еще предстоит выяснить.

Судя по каменному инвентарю, есть веские основания рассматривать неолитическую стоянку Кальмиус и Мариупольский могильник в качестве единого культурно-хронологического комплекса. При этом, видимо, хронологический диапазон могильника шире, чем время бытования раскопанных участков поселка.

\section{СПИСОК ЛИТЕРАТУРЫ}

1. Горелик, А. Ф. Старица XVIII - новая неолитическая стоянка в Среднем Подонцовье / А. Ф. Горелик, С. М. Дегерменджи, С. Н. Разумов // Археологический альманах. - № 18. - Донецк, 2006. - С.118-129.

2. Гиря, Е. Ю. Технологический анализ каменных индустрий. Методика микро- макроанализа древних орудий труда. Часть 2 / Е. Ю. Гиря. - СПб. : ИИМК РАН, 1997. - 198 с.

3. Гиря, Е. Ю. Сравнительный морфологический анализ полноты технологических контекстов каменных индустрий / Е. Ю. Гиря, В.М.Лозовский // 
Каменный век: от Атлантики до Пацифики. - СПб. : МАЭ РАН : ИИМК РАН, 2014. - С. 52-84. - (Замятнинский сборник ; вып. 3).

4. Горбов, Н. В. На границе культур: неолитический слой поселения Кальмиус и Мариупольский могильник / В. Н. Горбов, Р. П. Божко // Північне Приазов'я в епоху кам'яного віку - єнеоліту. - Мелітополь, смт. Мирне, 2013. - С. 34-40.

5. Гудименко, И. В. Оригинальная литейная форма палеометаллической эпохи / И. В. Гудименко, В. Я. Кияшко // Историко-археологические исследования в Азове и на Нижнем Дону в 1994 г. Выпуск четырнадцатый. - Азов : Азов. краевед. музей, 1997. - С. 102-112.

6. Даниленко, В. Н. Неолит Украины / В. Н. Даниленко. - Киев : Наукова думка, 1972. - 257 с.

7. Коваль, Ю. Г. Кремневый комплекс неолитического слоя поселения Кальмиус в современной черте г. Мариуполя (предварительное сообщение) / Ю. Г. Коваль, С. М. Дегерменджи // Північне Приазов' я в епоху кам'яного віку - єнеоліту. - Мелітополь, смт. Мирне, 2013. - С. 79-87.

8. Котова, Н. С. Неолитизация Украины / Н. С. Котова. - Луганск : Шлях, 2002. -268 с.

9. Макаренко, М. О. Маріюпильський могильник / М. О. Макаренко. - Київ : Вид-во ВУАК, 1933. $151 \mathrm{c}$.

10. Манько, В. О. Неоліт Південно-Східної України. Кам'яна доба України, вип. 9 / В. О. Манько. -Київ : Шлях, 2006. -280 с.

11. Сериков, Ю. Б. К вопросу об утилитарном и сакральном назначении так называемых утюжков / С. Б. Сериков // Проблемы археологии и древней истории Урала. - Нижний Тагил : НТГСПЛ, 2015. С. 185-197.

12. Телегин, Д. Я. Неолитические могильники мариупольского типа / Д. Я. Телегин. - Киев : Наукова думка, 1991. - 96 с.

13. Усачева, И. В. К вопросу о культурозависимых признаках у «утюжков» / И. В. Усачева // Вестник археологии, антропологии и этнографии. Тюмень : Изд-во ИПОС СО РАН, 2006. - № 1 (6). C. 4-11.

14. Усачева, И. В. «Утюжки» Евразии как исторический источник : автореф. дис. ... канд. ист. наук / Усачева Ирина Витальевна. - Екатеринбург, 2007. $23 \mathrm{c}$.

15. Усачева, И. В. Семиотический статус «утюжков» / И. В. Усачева // Вестник археологии, антропологии и этнографии. - Тюмень : Изд-во ИПОС СО PAH, 2011. - № 1 (14). - С. 22-27.

16. Усачева, И. В. «Утюжки» Евразии / И. В. Усачева. - Новосибирск : Наука, 2013. - 352 с.

17. Цыбрий, В. В. Исследование ранненеолитической стоянки Раздорская 2 в 2003 г. / В. В. Цыбрий // Историко-археологические исследования в
Азове и на Нижнем Дону в 2003 г. - Азов : Азов. краевед. музей, 2004. - С. 34-40.

18. Цыбрий, В. В. Неолит Нижнего Дона и Северо-Восточного Приазовья / В. В. Цыбрий. - Ростов н/Д : Изд-во СКНЦ ЮФУ, 2008. - 205 с.

19. Dibble, H. L. The interpretation of Middle Paleolithic Scraper Reduction Pattern / H. L. Dibble // Colloque international l'homme de Neandertal. Liége, 1996. - P. 61-76.

20. Dibble, H. On Assemblage Variability in the Middle Paleolithic of Western Europe / H. Dibble, N. Rolland // The Middle Paleolithic: Adaptation, Behavior, and Variability / eds. H. Dibble and P. Mellars. - University of Pennsylvania : University Museum Monograph, 1992. - 78. - P. 1-27.

21. Roebroeks, W. Planning depth, anticipation and organization of Middle Paleolithic technology: the "archaic natives" meet eve's descendants /W. Roebroek, J. Kolen, E. Resniks // Helinium. - 1988. XXVIII, 1. - P. 117-123.

22. Schild, R. Flint mining and trade in Polish prehistory as seen from the perspective of the chocolate flint of Central Polish. A second Approach / R. Schild // Acta Archaeologica Carpathica. - 1976. № 16. - P. 47-77.

23. Wechler, K-P. Studien zum Neolithikum der Osteurpaischen Steppe. Archaologie in Eurasien: Bd.12 / K.-P. Wechler. - Mainz, 2001. - 370 p.

\section{REFERENCES}

1. Gorelik A.F., Degermendzhi S.M., Razumov S.N. Staritsa XVIII - novaya neoliticheskaya stoyanka v Srednem Podontsovye [Staritsa XVIII -a New Neolithic Site on the Middle Podontsovye]. Arkheologicheskiy almanakh, 2006, no. 18, pp. 118-129.

2. Girya E.Yu. Tekhnologicheskiy analiz kamennykh industriy. Metodika mikro- makroanaliza drevnikh orudiy truda. Chast 2 [Technological Analysis of the Stone Industries. Technique of the Micro MacroAnalysis of Ancient Labor Tools]. Saint Petersburg, IIMK RAN Publ., 1997. 198 p.

3. Girya E.Yu., Lozovskiy V.M. Sravnitelnyy morfologicheskiy analiz polnoty tekhnologicheskikh kontekstov kamennykh industriy [Comparative Morphological Analysis of Completeness of Technological Contexts of the Stone Industries]. Kamennyy vek: ot Atlantiki do Patsifiki [Stone Age, from the Atlantic to the Pacific]. Saint Petersburg, MAE RAN Publ., IIMK RAN Publ., 2014, vol. 3, pp. 52-84. (Zamyatinsky Collection, iss. 3).

4. Gorbov N.V., Bozhko R.P. Na granitse kultur: neoliticheskiy sloy poseleniya Kalmius i Mariupolskiy mogilnik [On the Border of Cultures: a Neolithic Layer of the Settlement of Kalmius and the Mariupol Burial 
Ground]. Pivnichne Priazovya v epokhu kamyanogo viku - eneolitu [Azov Sea Cost during Stone Age Paleometal Age]. Melitopol, smt. Mirne Publ., 2013, pp. 34-40.

5. Gudimenko I.V., Kiyashko V.Ya. Originalnaya liteynaya forma paleometallicheskoy epokhi [Original Mold of Palymetallic Age]. Istoriko-arkheologicheskie issledovaniya v Azove i na Nizhnem Donu v 1994 g. [Historical and Archeological Investigations in the Azov and the Lower Don in 1994]. Azov, Azov. kraeved. muzey Publ., 1997, vol. 14, pp. 102-112.

6. DanilenkoV.N. Neolit Ukrainy [Neolithic Age of Ukraine]. Kyiv, Naukova dumka Publ., 1972. 257 p.

7. Koval Yu.G., Degermendzhi S.M. Kremnevyy kompleks neoliticheskogo sloya poseleniya Kalmius v sovremennoy cherte g. Mariupolya (predvaritelnoe soobshchenie) [A Flint Complex of a Neolithic Layer of the Settlement of Kalmius in Modern Borders of Mariupol (Preliminary Report)]. Pivnichne Priazovya v epokhu kamyanogo viku - eneolitu [Azov Sea Cost during Stone Age - Paleometal Age]. Melitopol, smt. Mirne Publ., 2013, pp. 79-87.

8. Kotova N.S. Neolitizatsiya Ukrainy [Neolitiztion of Ukraine]. Lugansk, Shlyakh Publ., 2002. $268 \mathrm{p}$.

9. Makarenko M. E. Mariyupilskiy mogilnik [Mariyupilsky Burial Place]. Kyiv, VUAK Publ., 1933. $151 \mathrm{p}$.

10. Manko V.O. Neolithic Southern Ukraine. Stone Age of Ukraine. Kiev, Shkyakh Publ., 2006, vol. 9. 280 p. (in Ukrainian).

11. Serikov Yu.B. K voprosu ob utilitarnom i sakralnom naznachenii tak nazyvaemykh utyuzhkov [On the Utilitarian and Sacral Purpose of So-Called Irons]. Problemy arkheologii i drevney istorii Urala [Problems of Archaeology and Ancient History of the Urals]. Nizhny Tagil, NTGSPL Publ., 2015, pp. 185-197.

12. Telegin D.Ya. Neoliticheskie mogilniki mariupolskogo tipa [Neolithic Burial Grounds of the Mariupol Type]. Kyiv, Naukova dumka Publ., 1991.96 p.

13. Usacheva I.V. K voprosu o kulturozavisimykh priznakakh u "utyuzhkov" [On the Culture Signs of the "Irons"]. Vestnik arkheologii, antropologii $i$ etnografii, 2006, no. 1 (6), pp. 4-11.
14. Usacheva I.V. "Utyuzhki” Evrazii kak istoricheskiy istochnik: avtoref. dis. ... kand. ist. nauk ["Irons" of Eurasia as a Historical Source. Dr. hist. sci. abs. diss.]. Ekaterinburg, 2007. 23 p.

15. Usacheva I.V. Semioticheskiy status "utyuzhkov" [Semiotic Status of the "Irons"]. Vestnik arkheologii, antropologii i etnografii, 2011, no. 1 (14), pp. 22-27.

16. Usacheva I.V. "Utyuzhki” Evrazii ["Irons" of Eurasia]. Novosibirsk, Nauka Publ., 2013. 352 p.

17. Tsybriy V.V. Issledovanie ranneneoliticheskoy stoyanki Razdorskaya 2 v 2003 g. [Research of the Early Neolithic Site Razdorskaya 2 in 2003]. Istorikoarkheologicheskie issledovaniya $v$ Azove $i$ na Nizhnem Donu v 2003 g. [Historical and Archaeological Research in the Azov and Lower Don in 2003]. Azov, Azov. kraeved. muzey Publ., 2004, pp. $34-40$.

18. Tsybriy V.V. Neolit Nizhnego Dona i SeveroVostochnogo Priazovya [Neolithic Age of Lower Don and Northeast Azov Sea Cost]. Rostov-on-Don, SKNTs YuFU Publ., 2008. 205 p.

19. Dibble H.L. The Interpretation of Middle Paleolithic Scraper Reduction Pattern. Colloque international l'homme de Neandertal - Liége, 1996, pp. 61-76.

20. Dibble H., Rolland N. On Assemblage Variability in the Middle Paleolithic of Western Europe. The Middle Paleolithic: Adaptation, Behavior, and Variability. University of Pennsylvania, University Museum Monograph 78, 1992, pp. 1-27.

21. Roebroeks W., Kolen J., Resniks E. Planning Depth, Anticipation and Organization of Middle Paleolithic Technology: the "Archaic Natives" Meet Eve's Descendants. Helinium, 1988, vol. XXVIII, no. 1, pp. 117-123.

22. Schild R. Flint Mining and Trade in Polish Prehistory as Seen From the Perspective of the Chocolate Flint of Central Polish. A Second Approach. Acta Archaeologica Carpathica, 1976, no. 16 , pp. $47-77$.

23. Wechler K-P. Studien zum Neolithikum der Osteurpaischen Steppe. Archaologie in Eurasien: Bd.12. Mainz, 2001.370 p. 